\title{
Identification and pathogenicity of microorganisms affecting purple passion fruit in Colombia
}

\author{
Joaquín Guillermo Ramírez Gil ${ }^{*}$, Pablo Julián Tamayo², Juan Gonzalo Morales ${ }^{1}$ \\ 10.1590/0034-737X201764030005
}

\begin{abstract}
Purple passion fruit (Passiflora edulis f. edulis Sims, known in Colombia as "gulupa") is an increasingly important crop in Colombia, as seen by an increase in the area under cultivation. This recent prominence coincides with a low number of existing technologies related to the cultivation of the fruit, resulting in a lack of knowledge about its associated pathogens and the absence of rapid and precise diagnostic tests. The objective of this study was to determine the pathogenicity of distinct microorganisms isolated from purple passion fruit samples, some of which had not been previously reported in Colombia. The sampling was performed in seven plots located in two regions of the Colombian Antioquia. With the use of field symptomatology, the isolation of microorganisms, morphological characteristics, molecular analysis, and pathogenicity tests, the pathogen species Phytophthora nicotianae var. parasitica, Colletotrichum gloeosporioides sensu lato, and Phytophthora drechsleri were identified for the first time in Colombia. These pathogens cause lesions in fruits, with an incidence of 10.9, 7.6, and 2.8\%, respectively. This is also the first report on a global level of Phytophthora drechsleri causing a disease in this plant species.
\end{abstract}

Key words: gulupa diseases; Phytopthora nicotianae var. parasitica; Colletotrichum gloeosporioides sensu lato; Phytophthora drechsleri.

\section{RESUMO}

\section{Identificação e patogenicidade de microorganismos que afetam maracujá roxo na Colômbia}

O Maracujá roxo (Passiflora edulis f. edulis Sims, conhecido na Colômbia como gulupa) é uma cultura cada vez mais importante na Colômbia, como visto por um aumento da área de cultivo. Esta proeminência recente coincide com o baixo número de tecnologias existentes relacionadas ao cultivo da fruta, resultando em falta de conhecimento sobre seus patógenos associados e da ausência de testes de diagnóstico rápido e preciso. Com o objetivo de determinar a patogenicidade de microorganismos distintos isolados de amostras de maracujá roxo, alguns dos quais não tinham sido previamente relatados na Colômbia. A amostragem foi realizada em sete lotes localizados em duas regiões de Antioquia Colômbia. Através da utilização de sintomatologia campo, o isolamento de microorganismos, as características morfológicas, a análise molecular e testes de patogenicidade, a espécies de agentes patogénicos Phytophthora nicotianae var. parasitica, Colletotrichum gloeosporioides sensu lato e Phytophthora drechsleri foram identificados pela primeira vez na Colômbia. Estes causam lesões nos frutos, com uma incidência de 10,9, 7,6e 2,8\%, respectivamente. Este é também o primeiro relatório em nível global de Phytophthora drechsleri causando uma doença nesta espécie de planta.

Palavras-chave: doenças gulupa; Phytopthora nicotianae var. parasitica; Colletotrichum gloeosporioides sensu lato; Phytophthora drechsleri.

\footnotetext{
Submitted on March 10 th, 2015 and accepted on April 19 $9^{\text {th }}, 2017$.

${ }^{1}$ Universidad Nacional de Colombia, Departamento de Ciencias Agronómicas, Medellin, Antioquia, Colombia. jgramireg@unal.edu.co; jgmoraleso@unal.edu.co

${ }^{2}$ Centro de Investigación La Selva de Corpoica, Rionegro, Antioquia, Colombia. ptamayo@corpoica.org.co

*Corresponding author: jgramireg@unal.edu.co
} 


\section{INTRODUCTION}

Purple passion fruit, also known as "gulupa" (Passiflora edulis f. edulis Sims), is a tropical fruit cultivated between 600 and 2,000 masl. The purple passion fruit is native to southern Brazil, Paraguay, and northern Argentina and is currently grown in four continents: Africa (Ivory Coast, Kenya, South Africa, and Zimbabwe), Asia (India, Indonesia, Israel, Malaysia, and Vietnam), Oceania (Australia and New Zealand), and America (Argentina, Brazil, Colombia, Peru, Ecuador, Paraguay, and Hawaii (USA)) (Ocampo \& Morales, 2012). This fruit is consumed domestically mainly in South America and is also grown for exportation (Nakasone \& Paull, 1998; Riascos et al., 2011; Ramírez et al., 2015). In Colombia, the area cultivated with purple passion fruit has grown in the last decade, particularly in the departments of Cundinamarca, Caldas, Antioquia, Huila, Boyaca, and Santander (Riascos et al., 2011; Gutiérrez et al., 2011, Ocampo et al., 2012; Ramírez et al., 2015). This increase in the planted area, coupled with the market demand for high quality, creates challenges and limits for production. One of the main problems in regard to maintaining competitiveness and sustainability is the diagnosis and management of diseases. Purple passion fruit is affected by various diseases with economic implications, which can generate production losses.

On a global level, various pathogenic microorganisms have been identified in purple passion fruit crops, including Xanthomonas axonopodis pv. passiflorae, Cladosporium cladosporioides sensu lato Fresen, Alternaria spp., Fusarium oxysporum f. sp. passiflorae, Fusarium solani (teleomorph: Nectria haematococca), Colletotrichum gloeosporioides Penz (teleomorph: Glomerella cingulata Stoneman), Phytophthora nicotianae var. parasitica, Phytoplasma spp., East Asian passiflora virus (EAPV), Maracuja mosaic tobamovirus (MarMV), Okra mosaic tymovirus (OkMV), Passiflora latent carlavirus (PLV), Passiflora virus Y(PaVY), Passion fruit crinkle virus (PCV), Passion fruit mottle virus (PFMoV), Passion fruit rhabdovirus (PRV), Passion fruit ringspot virus (PFRSV), Passion fruit vein-clearing rhabdovirus, Passion fruit woodiness potyvirus (PWV), Purple granadilla mosaic virus, and the nematode Meloidogyne incognita (Gardner, 1989; Yockteng et al., 2011).

Studies performed in Colombia have identified various agents that cause diseases in purple passion fruit, such as the bacteria Xanthomonas axonopodis and Stenotrophomonas maltophilia; the viruses Cucumber mosaic virus (CMV), Soybean mosaic virus (SBMV), Cowpea aphid-borne mosaic virus (CoABMV), and a potyvirus that has not been clearly identified; the fungi Cladosporium cladosporioides sensu lato (Weir et al., 2012), Fusarium oxysporum, and
Fusarium solani; and nematodes belonging to the genus Meloidogyne (Camelo, 2010; Benítez \& Hoyos, 2009; Riascos et al., 2011; Ortiz \& Hoyos, 2012). Other possible pathogens in purple passion fruit, which have not yet been verified, are Colletotrichum sp. and Botrytis sp. (Riascos et al., 2011).

This study was performed with the objective of determining the causal agent of various groups of symptoms associated with purple passion fruit diseases. Pathogenic microorganisms were identified causing high incidences of disease in purple passion fruit in the field. Two of these had not been previously reported in Colombia, the presence of one had not been confirmed, and one had never been reported on a global level.

\section{MATERIAL AND METHODS}

\section{Location}

Symptoms were examined and samples were taken from seven plots with purple passion fruit crops located in northwest Colombia, in Antioquia (Figure 1). Three of these were located in the southwest of Antioquia, in the city of Jardín, and four in the eastern region of Antioquia, two in the city of La Unión, and two in the city of El Peñól. Microbial identification and pathogenicity tests were performed in the Laboratory of Phytopathology at CORPOICA C.I. La Selva and Fitotecnia Tropical Laboratory in the Agronomical Sciences Department at Universidad Nacional de Colombia at Medellín. Molecular characterization of microorganisms was performed in the laboratory "Laboratorium ZeeuwsVlaanderen Zandbergsestraat" 14569 TC GRAAUW in The Netherlands.

\section{Sampling and isolation of microorganisms}

From each plot, 30 plants were selected at random, such that 15 had unripe, green colored fruits and 15 had physiologically mature fruits of a purple color. From each plant selected, 10 randomly distributed fruits with or without lesions were collected. The fruits were washed in the laboratory with water from the aqueduct and then air dried. Five of these were brought to a moist chamber for sporulation ( $85-95 \%$ humidity and $18-25^{\circ} \mathrm{C}$ ). The fruits that presented lesions, whether these were identified in the field or generated by incubation in the moist chamber, were divided into $1 \mathrm{~cm}^{3}$ pieces. These pieces were placed in a sterile laminar flow cabinet and the surfaces were disinfested with ethanol $(70 \%)$ for $30 \mathrm{~s}$. They were then washed in sterilized water for $30 \mathrm{~s}$. From these samples, small pieces were taken $\left(3 \mathrm{~mm}^{3}\right)$ and placed amid cultures of potato, dextrose, and agar, acidified with lactic acid (PDAA pH 5.5); potato, dextrose, agar + streptomycin (100 $\mu \mathrm{g} / \mathrm{L})(\mathrm{PDA}+\mathrm{S})$; V8® juice $(180 \mathrm{~mL} / \mathrm{L})+\operatorname{agar}(14 \mathrm{~g} / \mathrm{L})+$ kanamycin $(50 \mu \mathrm{g} / \mathrm{L})+$ Benomyl® $(50 \mu \mathrm{g} / \mathrm{L})(\mathrm{V} 8-\mathrm{A})$; 
Nutritious Agar (Merck®), prepared according to the manufacturer's instructions (NA) and Nutritious Agar $\left(\right.$ Merck $\left.{ }^{\circledR}\right)+$ Benomyl ${ }^{\circledR}(50 \mu \mathrm{g} / \mathrm{L})(\mathrm{NAB})$ for bacteria. The Petri dishes with these substances were incubated at $28{ }^{\circ} \mathrm{C}$ for 15 days, with a photoperiod of $12 \mathrm{~h}$ of light and $12 \mathrm{~h}$ of darkness (Ramírez et al., 2014). The pathogens not reported previously in Colombia (Buriticá, 1999; Camelo, 2010; Benítez \& Hoyos, 2009; Riascos et al., 2011; Ortiz \& Hoyos, 2012), were identified using taxonomic keys and positive pathogenicity tests

\section{Taxonomical identification of microorganisms}

Micro-assemblies were created using tissue samples that underwent sporulation in the moist chamber and isolates obtained from the cultures. These micro-assemblies were observed under the light microscope (Nikon $®$ Eclipse E200) to identify them using the criteria described in the manuals for fungi genera by Barnett \& Hunter (1998), Seifert et al. (2011) and by Erwin \& Ribeiro (1996) for the
Phytophthora genus and species. For Colletotrichum species identification, recent concepts from Weir et al. (2012) were used. Bacteria were identified using the process described by Benítez \& Hoyos (2009). Morphological characterization of the microorganisms was performed by measuring the length (L) and width (W) and calculating the relationship (L:W) in 20 conidia for each isolate of fungi or oomycete sporangia.

For molecular identification, diseased fruits showing typical symptoms obtained from sampling lots (Jardín, Antioqua, Colombia) were sent to the molecular diagnostics laboratory "Laboratorium Zeeuws-Vlaanderen Zandbergsestraat 14569 TC GRAAUW", located in The Netherlands. Isolates were identified based on the DNA Multiscan Vegetables $®$, molecular analysis method, which uses PCR amplification and specific DNA membrane hybridization revealing black spots for sensitive pathogen detection (http://www.relabdenhaan.com/Pages/Content/ Default.aspx?L=2\&P=133 accessed on March 05, 2015).

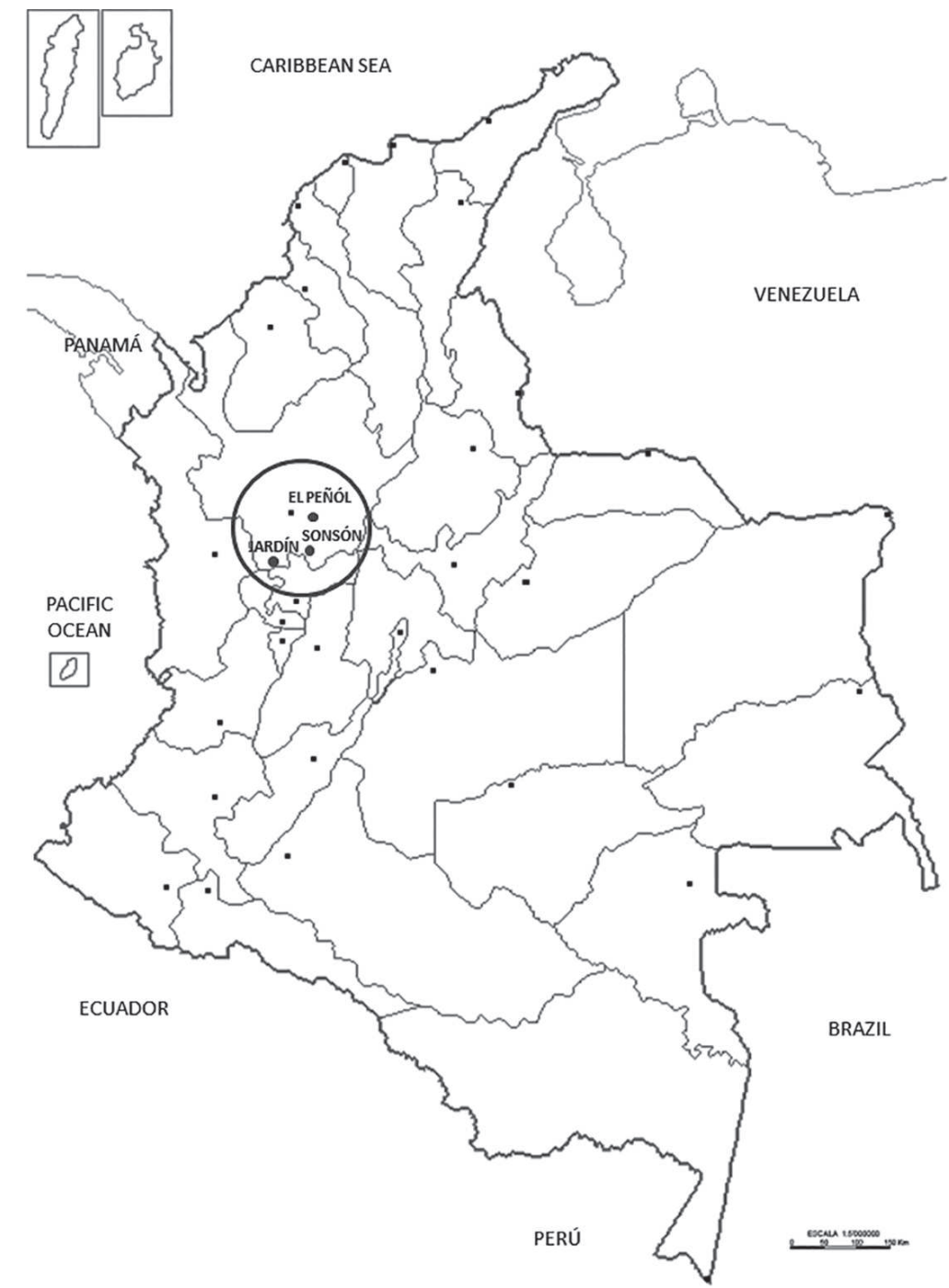

Figure 1: Geographical localization of sampling regions where disease symptoms were identified in Passiflora edulis f. edulis Sims (gulupa) crops 


\section{Pathogenicity tests}

The isolates obtained were inoculated into healthy, ripe fruits, which had been disinfested as described previously. Inoculum for each microorganism was quantified in a Neubauer chamber and dissolved in an agar-water solution of $2 \%$ (w/v). Five drops of $20 \mu \mathrm{L}$ were placed on each inoculated fruit and the fruits were then incubated under the conditions described earlier. For the Phytophthora spp., the mycelia grew in PDA media incubated under an incandescent light. A suspension of 3,000 sporangia $/ \mathrm{mL}$ was prepared. For C. gloeosporioides sensu lato, the mycelia grew in the PDA and a suspension of $1 \times 10^{5} \mathrm{conidia} / \mathrm{mL}$ was prepared. Each pathogen was inoculated into five fruits. The variables evaluated after inoculation (a.i.) were: average symptom appearance time (ASAT) and average fruit sporulation time (AST). Additionally, the characteristic symptoms associated with each isolate were registered.

\section{Incidence}

The pathogens not reported previously in Colombia were identified using taxonomic keys and positive pathogenicity tests. For each one, the incidence was calculated as a function of the number of fruits collected with microorganisms present divided by the total number of fruits collected.

\section{Statistical Analysis}

The average and standard deviation for the information obtained by measuring the morphological structures of the microorganisms identified was determined using Microsoft ${ }^{\circledR}$ Excel. For the ASAT and AST variables, ANOVA test and the Tukey means separation test were performed, with a significance level of $95 \%$.

\section{RESULTS AND DISCUSSION}

\section{Phytophthora nicotianae var. parasitica}

This microorganism was isolated in the V8-A culture using fruits that presented lesions of varying sizes, with a rounded shape, a green to light brown color, and a stronger tone around the edges. As it is characteristic in advanced stages, the lesions coalesced until they covered the entire fruit (Figure 2 A, B, C). The pure isolates were compared in the PDA general growth medium, where they exhibited slow growth, irregular submersion, many swellings and hyphal vesicles, and unbranching, monochasially branched or monopodially branched sporangiophores (Figure $3 \mathrm{~A}$ ). The sporangia were abundant, terminal, sporadically intercalated or lateral, symmetric, and of an ellipsoidal, ovoid, or piriform shape, with very prominent hemispheric papilla (Figure $3 \mathrm{~B}$, Table 1). Chlamydospores and sexual structures were absent. Based on the morphological characteristics of the isolates (Erwin \& Ribeiro, 1996) and the molecular diagnostic report using the DNA Multiscan Vegetables ${ }^{\circledR}$, the microorganism associated with this pathology was identified as Phytophthora nicotianae var. parasitica.

The incidence of the symptoms caused by $P$. nicotianae in the field was $12.9 \%$ in the southwestern region and $8.9 \%$ in the eastern region. This type of symptom was associated with fruits in all states of maturity, but was most extreme in the youngest fruits, located mainly inside the plant between the lowest part and the middle third. The farmers who were consulted stated that these symptoms were new to them and occurred most intensely during periods of high precipitation.

The presence of $P$. nicotianae var. parasitica had not been reported previously in Colombia affecting $P$. edulis $\mathrm{f}$. edulis (Buriticá, 1999). At a global level, it has been reported in P. edulis f. edulis in India, South Africa, Australia, and New Zealand, where it causes serious diseases with symptoms characterized by foliar blemishes, root rot, and fruit rot. It causes outbreaks mainly in periods of high precipitation (Cole et al., 1992). The incidence of disease caused by $P$. nicotianae var. parasitica in land plots evaluated in Antioquia was $10.9 \%$, indicating its significance; however, the farmers affirmed that the associated characteristic symptoms have appeared recently in commercial crops, linked to the periods of increased precipitation that occurred in 2010 and 2011, during the meteorological phenomenon La Niña.

\section{Colletotrichum gloeosporioides sensu lato}

A similar microorganism was isolated from fruits in all stages of maturity in the field, which exhibited light colored patches of an irregular shape. Upon being harvested and incubated in a moist chamber, the fruits showed a rapid advancement in symptoms until the lesions became large and dark colored and took on a depressed shape. In advanced states, pathogenic structures were observed, represented by fructiferous bodies of a black and pink color (Figure 2 D, E and F). From these lesions, a fungus was isolated, which presented rapid growth $(2 \mathrm{~mm} /$ day $)$ in the PDAA and PDA+S media culture. The mycelia displayed a soft gray color on the outer part, which became more intense near the center (Figure $3 \mathrm{C}$ ). In both the diseased tissue and the mycelia grown in the culture medium, unicellular, rounded hyaline conidia were observed (Figure 3 D). The morphological structures observed and the results reported from the DNA Multiscan Vegetables ${ }^{\circledR}$ molecular test were consistent with the fungus C. gloeosporioides sensu lato (Barnett \& Hunter, 1998; Ureña et al., 2002, Weir et al., 2012). Recent studies have indicated that the Colletotrichum genus is more complex than was previously believed. The name $C$. gloeosporioides sensu lato or $C$. gloeosporioides species complex, has been given to the taxonomical group that 


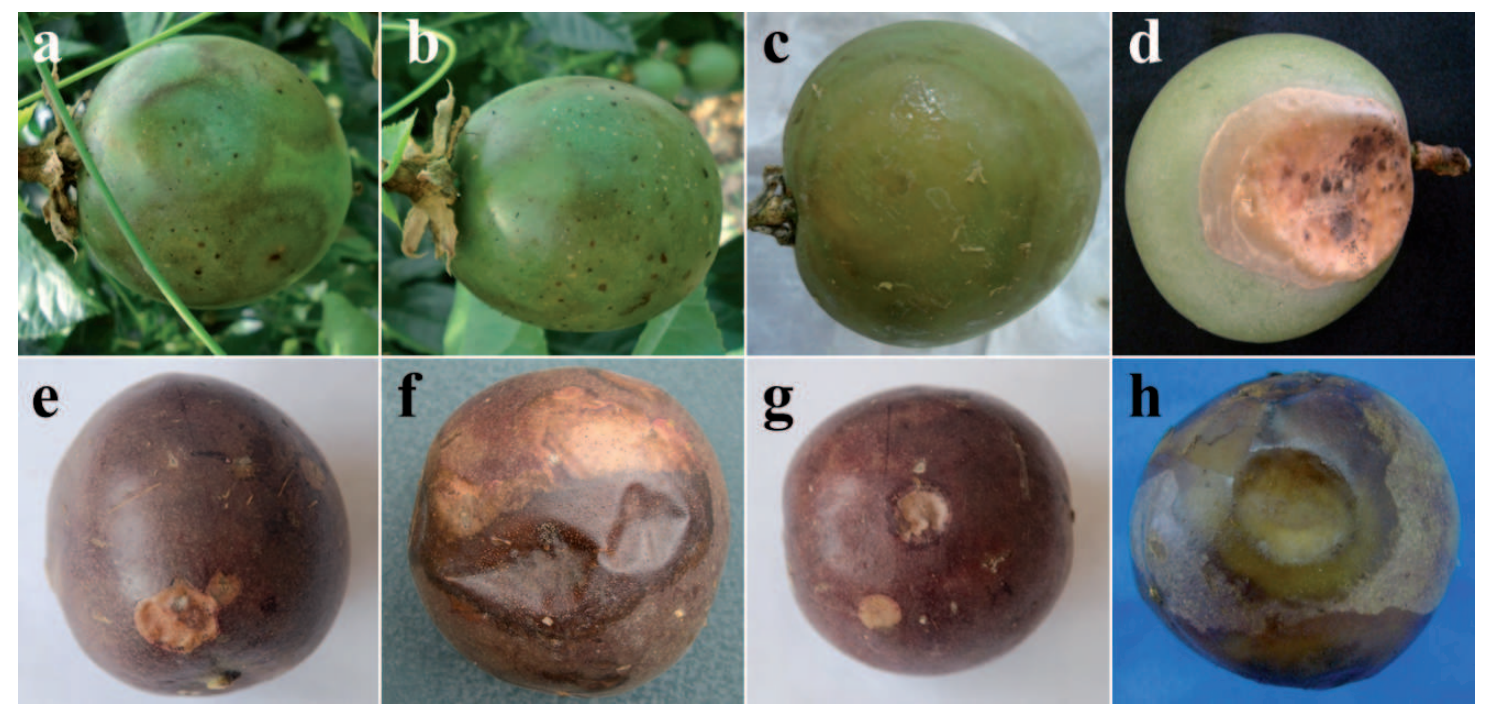

Figure 2: Phytophthora nicotianae var. parasitica, Colletotrichum gloeosporioides sensu lato, and Phytophthora drechsleri associated symptoms in Passiflora edulis f. edulis Sims (gulupa) fruits a, b, and c: Phytophthora nicotianae var. parasitica associated symptoms; $\mathrm{d}, \mathrm{e}$, and f: Colletotrichum gloeosporioides sensu lato associated symptoms; $\mathrm{g}$ and h: Phytophthora drechsleri associated symptoms.

displays morphological characteristics typical of $C$. gloeosporioides, as it has been known for the past 50 years and which is grouped within the phylogenetic tree of the ITS gene genetic barcode (Weir et al., 2012). In the present study, the causal agent identified will be referred to by this name.

The incidence of plants with symptoms of this disease was $10.6 \%$ in the eastern region and $4.6 \%$ in the southwestern region. Passion fruit farmers identified these symptoms as a common problem and their technical assistants have associated them with the fungus $C$. cladosporioides sensu lato. The fungus $C$. gloeosporioides has been reported as causing anthracnosis in purple passion fruit in New Zealand, Argentina, Brazil, and Japan. In Colombia, no reports exist that clearly demonstrate, by fulfilling all of Koch's postulates, that $C$. gloeosporioides causes any diseases in purple passion fruit (Riascos et al., 2011; Wolcan \& Larran, 2000; Rheinländer, 2010).

Despite the fact that $C$. gloeosporioides sensu lato was found under field conditions in immature states of the fruit, the greatest presence and associated symptoms of this pathogen were found in fruits with an advanced state of maturity, especially in the post-harvest stage. This was confirmed with the pathogenicity tests, which showed a slow appearance of these symptoms, compared with those of other pathogens evaluated in the present study. This observation coincides with that reported by Rheinländer (2010), who proposed that this pathogen commonly causes an asymptomatic infection in the field. According to Beno \& Prusky (2000) and Rodríguez et al. (2009), in the diseases caused by species of the genus Colletotrichum, quiescent behavior is common in the field, followed by a greater incidence of symptoms in the post-harvest period.
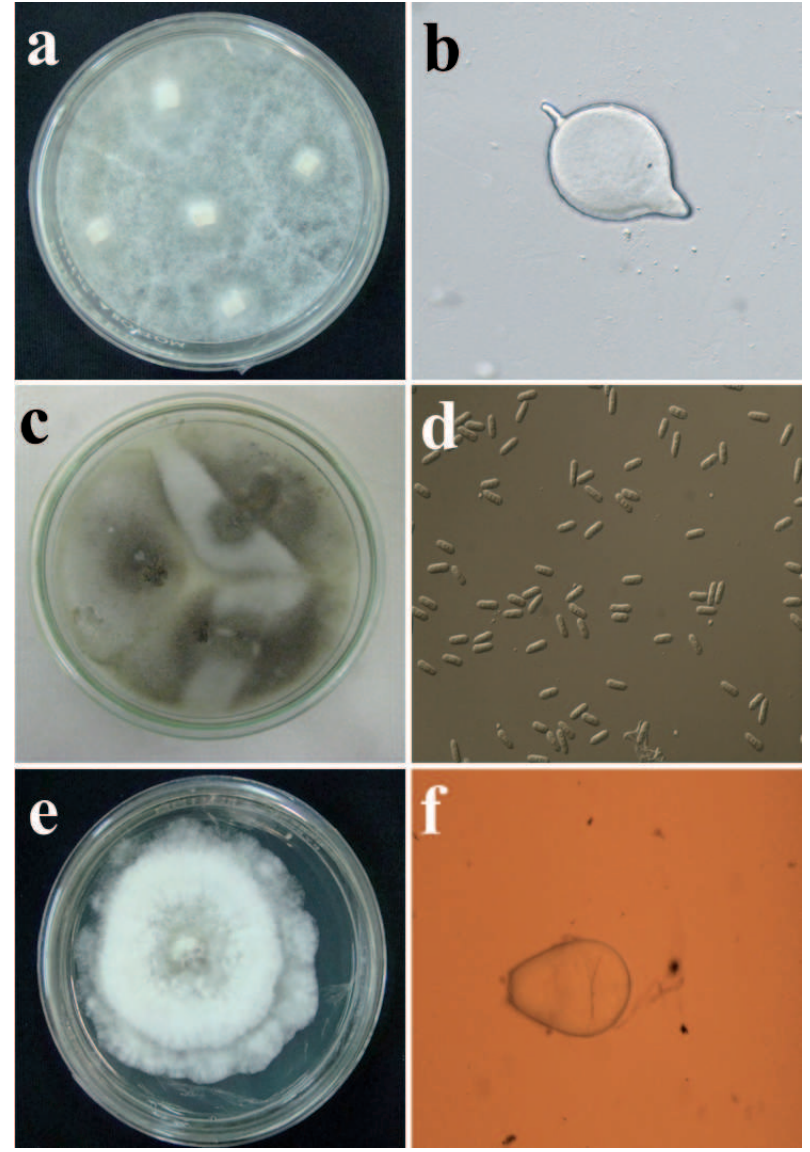

Figure 3: Morphological structures identified in isolates of Phytophthora nicotianae var. parasitica, Colletotrichum gloeosporioides sensu lato, and Phytophthora drechsleri, collected from Passiflora edulis f. edulis Sims (gulupa) fruits a and b: Phytophthora nicotianae var. parasitica colony growing on PDA culture media and sporangium (400x). c and d: Colletotrichum gloeosporiodes sensu lato colony growing on PDA culture media and conidia (400X); e and f: Phytophthora drechsleri colony growing on PDA culture media and sporangium (400X). 
This could be associated with the physiological changes that occur in the fruit in this stage, which may facilitate the penetration of the pathogen in the fruit tissue.

\section{Phytophthora drechsleri}

In fruits in all stages of development in the field, small, rounded, well-defined lesions of a light brown color were observed. Upon incubating the fruits in the moist chamber, the lesions developed rapidly, until they took on an irregular shape that was depressed in the center and of a moist consistency. In advanced stages, necrosis was observed on the edges, as well as coalescence and extensive dead tissue (Figure $2 \mathrm{G}, \mathrm{H}$ ). Isolates from the diseased tissue were obtained only from the V8-A medium. After purification, they exhibited growth in the form of a chrysanthemum in the PDA medium (Figure $3 \mathrm{E}$ ). The isolates exhibited sympodial, unbranched sporangiophores, and ovoid or oviform, unpapillated, and persistent sporangia (Figure $3 \mathrm{~F}$, Table 1). Chlamydospores and sexual structures were absent. The morphological structures observed and reports from the DNA Multiscan Vegetables ${ }^{\circledR}$ molecular test corresponded to the oomycete P. drechsleri (Erwin \& Ribeiro, 1996).

The incidence of this microorganism was $2.8 \%$ for the area evaluated and it was only observed in two plots of land in the southwestern region of Antioquia. The farmers and technical assistants consulted associated these symptoms with the fungus $C$. cladosporioides sensu lato or with the disease called scab, caused by the bacteria Xanthomonas axonopodis.

P. drechsleri was found to affect P. edulis f. edulis fruits only in crops located in southwestern Antioquia.
This microorganism had not been previously reported in this host on a global level (Inch, 1978; Buriticá, 1999; Manicom et al., 2003; Fischer \& Rezende, 2008; Yockteng et al., 2011). P. drechsleri affects a wide range of hosts, among them native forest species, cultivated and noncultivated flowers, citrus plants, melons, tomatoes, and others (Pratt et al., 1974; Cother, 1975; Lamour et al., 2003). This pathogen usually causes symptoms such as foliar blemishes and fruit rot (Cother, 1975).

\section{Other microorganisms}

In this study, the bacteria Xanthomonas axonopodis and the fungus Cladosporium cladosporioides sensu lato, which cause damage to fruits, were also identified. These microorganisms had already been reported previously in Colombia (Riascos et al. 2011).

\section{Pathogenicity tests}

Through the use of pathogenicity tests performed with the purple passion fruits, it was possible to reproduce symptoms for the microorganisms $P$. nicotianae var. parasitica, C. gloeosporiodes sensu lato, and $P$. drechsleri (Table 2). The isolates $P$. nicotinae var. parasitica and $P$. drechsleri were the microorganisms that induced the appearance of symptoms in the shortest average time (12.15 and 17.8 days, respectively). The shortest time for sporulation was observed with the isolate $P$. nicotianae var. parasitica (23.1 days) (Table 2). Koch's postulates were fulfilled for the isolates of these three microorganisms.

In Colombia, there have been few studies performed aiming at identifying diseases that affect purple passion

Table 1: Quantification of morphological structures identified from the microorganisms isolated from Passiflora edulis f. edulis Sims. (gulupa) fruits

\begin{tabular}{|c|c|c|c|c|}
\hline Microorganism & Morphological structure $^{1}$ & $\mathbf{L}^{2}$ & $\mathbf{W}^{3}$ & $\mathbf{L}: \mathbf{W}^{4}$ \\
\hline Phytophthora nicotinae var. parasitica & Sporangium & $45 \pm 25$ & $31 \pm 20$ & $1.4 \pm 0.5$ \\
\hline Colletotrichum gloeosporiodes sensu lato & Conidium & $14.8 \pm 2$ & $4.3 \pm 1$ & $3.4 \pm 1$ \\
\hline Phytophthora drechsleri & Sporangium & $34.8 \pm 20$ & $25.2 \pm 15$ & $1.3 \pm 0.5$ \\
\hline
\end{tabular}

${ }^{1}$ Taxonomic determinants identified from fruits and culture media.

${ }^{2}$ Lenght of the identified structure in $\mu \mathrm{m}$.

${ }^{3}$ Width of the identified structure in $\mu \mathrm{m}$.

${ }^{4}$ Length:width ratio.

Data are presented as the average of 20 independent measurements for each morphological structure \pm standard deviation.

Table 2: Pathogenicity test results

\begin{tabular}{lccl}
\hline Microorganism & AASAT & AAST & \multicolumn{1}{c}{ Symptom } \\
\hline Phytophthora nicotinae var. parasitica & $12.15 \mathrm{~b}$ & $23.1 \mathrm{~b}$ & Fruit rot exhibiting pronounced edges. \\
Colletotrichum gloeosporiodes sensu lato & $45.9 \mathrm{a}$ & $53.2 \mathrm{a}$ & Tissue necrosis showing depressed lesion in advanced stages. \\
Phytophthora drechsleri & $17.8 \mathrm{~b}$ & $26.3 \mathrm{~b}$ & Depressed lesion light brown colored. \\
\hline
\end{tabular}

Pathogenicity tests were performed on healthy fruits collected during physiological maturity. Five fruits were inoculated with each microorganism.

ASAT - average symptom appearance time in days;

AST: average fruit sporulation time (AST)

Different letters indicate statistical differences according to the Tukey test $(\mathrm{P}<0.05)$. 
fruit. The majority of them have occurred in the Cundinamara department (Riascos et al., 2011; Camelo, 2010; Benítez \& Hoyos 2009). An increase in exportations of fruits, such as purple passion fruit, requires improved monitoring of crop health, so that management plans that are appropriate, effective, and consistent with the requirements of the national and international markets can be implemented. The symptoms of the diseases present in purple passion fruit crops can be easily confused, leading to incorrect management of the problem, which can cause contamination, resistance to pesticides, and an increase in losses and costs, among other problems. For example, the characteristic symptoms in fruits and leaves caused by $P$. nicotinae var. parasitica could be easily confused in the field with those reported for Xanthomonas axonopodis pv. passiflorae (Benítez \& Hoyos, 2009). Additionally, the microorganisms identified in the present study belong to different taxonomical groups since they are fungi and oomycetes. This means that their chemical control could require the use of molecules that are effective against one group, but not against the other. For this reason, an imprecise diagnosis could lead to high costs without controlling the disease, notably affecting the sustainability of the crop.

The results of this study could contribute to the technical development of the purple passion fruit crop in Colombia and in other parts of the world. This is urgently needed, due to the increase in cultivation in tropical countries as a result of increased consumption in Europe (Ulmer \& MacDougal 2004). This study also points to the need to perform a larger sampling aiming at identifying other diseases and defining the economic implications of the three that were found in this study, in the distinct farming regions of Colombia. In addition, evaluations should be initiated regarding management practices. These should be aimed at creating an integrated plan that involves appropriate practices, is easily applied, and has been adapted to the farmers' socioeconomic conditions.

\section{CONCLUSIONS}

In this study, the pathogen Phytophthora nicotinae var. parasitica was identified for the first time as affecting purple passion fruit.

The presence of Colletotrichum gloeosporioides sensu lato was confirmed, and Phytophthora drechsleri was identified for the first time on a global level as causing lesions in purple passion fruit.

\section{ACKNOWLEDGMENTS}

Authors are very grateful with gulupa producers for their valuable help. The present work was financed by CORPOICA and Universidad Nacional de Colombia sede Medellín.

\section{REFERENCES}

Barnett H \& Hunter B (1998) Illustrated genera of imperfect fungi. $4^{\text {th }}$ ed. Minneapolis, Burgess Publishing Company. 218p.

Beno DB \& Prusky D (2000) Early events during quiescent infection development by Colletotrichum gloeosporioides in unripe avocado fruits. Phytopathology, 90:553-559.

Benítez S \& Hoyos L (2009) Sintomatología asociada a bacteriosis en zonas productoras de gulupa (Passiflora edulis Sims.) en Colombia. Revista Colombiana de Ciencias Hortícolas, 3:275-279.

Buriticá PE (1999) Directorio de patógenos y enfermedades de las plantas de importancia económica en Colombia. Santafé de Bogotá, Universidad Nacional de Colombia / Instituto Colombiano Agropecuario. 329p.

Camelo V (2010) Detección e identificación de los virus patógenos de cultivos de gulupa (Passiflora edulis Sims.) en la región del Sumapaz. Tesis de Maestría. Universidad Nacional de Colombia, Bogotá. 60p.

Cole DL, Hedges TR \& Ndowora T (1992) A wilt of passion fruit (Passiûra edulis f. edulis Sims) caused by Fusarium solani and Phytophthora nicotianae var. parasitica. International Journal of Pest Management, 38:362-366.

Cother EJ (1975) Phytophthora drechsleri: pathogenicity testing and determination of effective host range. Australian Journal of Botany, 23:87-94.

Erwin DC \& Ribeiro OK (1996) Phytophthora Diseases Worldwide. The American Phytophathological Society, St. Paul, American Phytopathological Society Press. 562p.

Fischer I \& Rezende J (2008) Diseases of passion flower (Passiflora spp.). Pest Technology, 2:01-19.

Gardner D (1989) Pathogenicity of Fusarium oxysporum f.sp. passiflorae to banana poka and other Passiflora spp. in Hawaii. Plant Disease, 73:476-478.

Gutiérrez M, Miranda D \& Cárdenas J (2011) Efecto de tratamientos pre-germinativos sobre la germinación de semillas de gulupa (Passiflora edulis Sims.), granadilla (Passiflora ligularis Juss.) y cholupa (Passiflora maliformis L.). Revista Colombiana de Ciencias Hortícolas, 5:209-219.

Inch AJ (1978) Passion fruit diseases. Queensland Agricultural Journal, 104:479-484.

Lamour KH, Daughtrey ML, Benson DM, Hwang J \& Hausbeck MK (2003) Etiology of Phytophthora drechsleri and $P$. nicotianae (=P. parasitica) diseases affecting floriculture crops. Plant Disease, 87:854-858.

Manicom B, Ruggiero C, Ploetz RC \& Goes A (2003) Diseases of Passion fruit. In: Ploetz RC (Ed.) Diseases of tropical fruit crops. Wallingford, CAB international. p.413-441.

Nakasone H \& Paull RE (1998) Tropical fruits. Washington, CAB Internacional. 464p.

Ocampo J \& Morales G (2012) Aspectos generales de la Gulupa (Passiflora edulis f. edulis Sims). In: Ocampo J \& Wyckhuys K (Eds.) Tecnología para el cultivo de la Gulupa en Colombia (Passiflora edulis f. edulis Sims) Purple Passion Fruit. Bogotá, Centro de Bio-Sistemas de la Universidad Jorge Tadeo Lozano / Centro Internacional de Agricultura Tropical / Ministerio de Agricultura y Desarrollo Rural. p.07-12.

Ocampo J, Marín C, López C \& Casas A (2012) Manejo del cultivo de la Gulupa (Passiflora edulis f. edulis Sims). In: Ocampo J \& K Wyckhuys (Eds.) Tecnología para el cultivo de la Gulupa en Colombia (Passiflora edulis f. edulis Sims) Purple Passion Fruit. Bogotá, Centro de Bio-Sistemas de la Universidad Jorge Tadeo Lozano / Centro Internacional de Agricultura Tropical / Ministerio de Agricultura y Desarrollo Rural. p.38-43. 
Ortiz E \& Hoyos L (2012) Descripción de la sintomatología asociada a fusariosis y comparación con otras enfermedades en gulupa (Passiflora edulis Sims.) en la región del Sumapaz (Colombia). Revista Colombiana de Ciencias Hortícolas, 6:110116.

Pratt BH, Heather WA \& Shepherd CJ (1974) Pathogenicity to three agricultural plant species of Phytophthora drechsleri isolates from Australian forest communities. Australian Journal of Botany, 22:09-12.

Ramirez JG, Castañeda DA \& Morales JG (2014) Estudios etiológicos de la marchitez del aguacate en Antioquia-Colombia. Revista Ceres, 61:050-061.

Ramirez JG, Muños M, Osorno L, Osorio NW \& Morales JG (2015) Germination and growth of purple passion fruit seedlings under pre-germination treatments and mycorrhizal inoculation. Pesquis Agropecuária Tropical, 45:257-265.

Rheinländer PA (2010) Field Guide to common diseases and disorders of passion fruit in New Zealand. Auckland, Institute for Plant \& Food Research Mt Albert. 40p.

Riascos D, Quiroga I \& Hoyos L (2011) Análisis de la sintomatología de la roña en gulupa (Passiflora edulis f. edulis Sims). Agronomía, 19:20-30.
Rodríguez E, González R, Mayek J \& Netzahualcoyotl J (2009) La Infección de Colletotrichum gloeosporioides (Penz.) Penz. y Sacc. en Aguacatero (Persea americana Mill.): Aspectos Bioquímicos y Genéticos. Revista Mexicana de Fitopatología, 27:53-63.

Seifert K, Morgan-Jones G, Gams W \& Kendrick B (2011) The Genera of Hyphomycetes. Utrecht, CBS-KNAW Fungal Biodiversity Centre. 997p. (CBS Biodiversity Series, 9).

Ulmer T \& MacDougal J (2004) Passiûora: passion flowers of the world. Portland, Timber Press. 432p.

Ureña PA, MacKenzie SJ, Bowen BW \& Legard DE (2002) Etiology and population genetics of Colletotrichum spp. causing crown and fruit rot of strawberry. Phytopathology, 92:12451252 .

Weir B, Johnston P \& Damm U (2012) The Colletotrichum gloeosporioides species complex. Studies in Mycology, 73:115180 .

Wolcan S \& Larran S (2000) First report of anthracnose caused by Glomerella cingulata ana: Colletotrichum gloesporioides) on passion fruit in Argentina. Plant Disease, 84:706.

Yockteng R, Eeckenbrugge G \& Souza-Chies T (2011) Passiflora. In: Kole C (Ed.) Wild Crop Relatives: Genomic and Breeding Resources. Tropical and Subtropical Fruits. New York, Springer. p.159-171. 